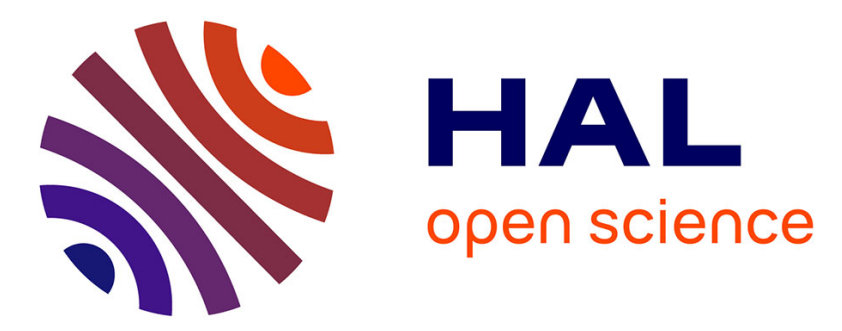

\title{
IS IT POSSIBLE TO ACHIEVE QUALITY LIGHTING WITHOUT CONSIDERING THE PHOTOMETRY OF THE PAVEMENTS?
}

Valérie Muzet, Sébastien Liandrat, Vincent Bour, Jérôme Dehon, Jean-Pierre Christory

\section{To cite this version:}

Valérie Muzet, Sébastien Liandrat, Vincent Bour, Jérôme Dehon, Jean-Pierre Christory. IS IT POSSIBLE TO ACHIEVE QUALITY LIGHTING WITHOUT CONSIDERING THE PHOTOMETRY OF THE PAVEMENTS?. Conference CIE 2021, NC Malaysia, CIE, Sep 2021, Kuala Lumpur, Malaysia. pp.11-25. hal-03405105

\section{HAL Id: hal-03405105 https://hal.science/hal-03405105}

Submitted on 4 Nov 2021

HAL is a multi-disciplinary open access archive for the deposit and dissemination of scientific research documents, whether they are published or not. The documents may come from teaching and research institutions in France or abroad, or from public or private research centers.
L'archive ouverte pluridisciplinaire HAL, est destinée au dépôt et à la diffusion de documents scientifiques de niveau recherche, publiés ou non, émanant des établissements d'enseignement et de recherche français ou étrangers, des laboratoires publics ou privés. 


\title{
IS IT POSSIBLE TO ACHIEVE QUALITY LIGHTING WITHOUT CONSIDERING THE PHOTOMETRY OF THE PAVEMENTS?
}

\author{
Muzet, V. ${ }^{1}$, Liandrat S. ${ }^{2}$, Bour V. ${ }^{3}$, Dehon J. ${ }^{4}$ Christory J.P. ${ }^{5}$ \\ ${ }^{1}$ Cerema ENDSUM, Strasbourg, FRANCE, ${ }^{2}$ Cerema STI, Clermont Ferrand, FRANCE, \\ ${ }^{3}$ AFE, Roissy, FRANCE, ${ }^{4}$ Schréder, Liège, BELGIQUE, ${ }^{5}$ Consultant, Rambouillet, FRANCE \\ valerie.muzet@cerema.fr
}

DOI 10.25039/x48.2021.OP01

\begin{abstract}
In this study, the photometry of a wide range of classic and innovative pavements used in urban and interurban areas were characterised both when new and after 30 months of natural aging. An extreme diversity of behaviour with respect to light reflection was revealed both over time and between pavements. The simulations of relamping cases show that the use of typical CIE $r$-tables almost systematically leads to non-compliance with the EN 13201 standard, particularly in terms of uniformity. Taking the photometry of the pavement at its stabilized state into account, simultaneously allows for compliance with lighting safety issues and for significant energy savings. As measurements of pavement photometry are rarely carried out, an alternative is to build up a database of urban pavements, which is one of the objectives of the Pavements and Lighting working group.
\end{abstract}

Keywords: Pavement photometry, Gonioreflectometer, Aging effect, Database, Road lighting design, Relamping

\section{Introduction}

The lighting installations are designed on the principle of "projected light flux" on a standard road surface. The important for the user is not only the projected luminous flux, but the light reflected by the pavement or the obstacle and thus the luminance. The perception is done by contrast of luminance and this one depends on the properties of the pavement. Road lighting installations are generally designed by calculating the performance in terms of luminance distribution as defined in (CIE 140, 2019) and the EN 13201 European standard (EN 13201-3, 2015). Since the photometric characteristics of the pavements are generally not measured, a standard $r$-table as defined in (CIE 144, 2001) is often used for lighting design. The "standard" $r$-tables are more than 50 years old and several studies have shown that they are no longer representative of actual pavements (Dumont, 2007, Jackett, 2009, Gidlund, 2019, Muzet, 2019a).

Over the past thirty years, several technical, technological, regulatory and societal changes have gradually led to a questioning of the way in which lighting installations are designed and calculated:

- Diversity of road surfaces: we have gone from a few standard road surfaces to an increasingly varied range of surfaces, meeting the requirements of safety, comfort, aesthetics, space structuring and environment. Streets used to be designed and built with the same pavements as roads, this is no longer the case today. Road surfaces, especially urban surfaces, now have such a wide range of surface characteristics (colour, texture, shape) that their photometric properties have been expanded and diversified. The photometric properties of many of them were never measured.

- Technological evolution of lighting systems: the new technologies in lighting installation expand the range of materials and bring more flexibility in their operation,

- Regulatory changes: the NF EN 13201 standard for public lighting allows the project manager to define "photometric levels" and to optimize the project by activating three levels: the equipment, the coating and the organization of the ground plan, 
- Societal evolution of street lighting issues: in addition to its primary function of improving safety, in recent years customers have become increasingly aware of the need to reduce energy waste and, above all, to reduce the impact on the environment in order to improve the comfort and lifestyle of citizens.

Despite all these evolutions, it was recently shown in the SURFACE European project that the standard $r$-tables R3 and C2 are the most used all over the world (Muzet, 2019b), despite the fact that their use can generate important errors (more than $30 \%$ ) for the average luminance (Chain, 2007, Gidlund, 2019, Muzet, 2019a).

The Pavement and Lighting working group ( $P \& L$ group or in French Revêtement et Lumière) is composed of project managers and public authorities ${ }^{*}$, professional associations and unions of lighting designers ${ }^{* *}$ and road builders ${ }^{\sim}$, public and private research organisations ${ }^{\perp}$ and expert consultants. After organizing and monitoring demonstrators and operations on real sites to show the relevance of the challenges and concepts of optimal lighting (Abdo, 2010, Christory, 2014), our goal consists in elaborating a library of actual and innovative urban pavements available on the market to:

- facilitate the choice of decision makers,

- develop tools and methods for managers, lighting designers and road builders to optimize lighting both in interurban and urban areas.

Nowadays the important renewing of lighting installation with a lot of LED relamping creates major new opportunities for road and public space operators. Can these new installations comply with the EN 13201 standard without taking into account the actual road photometry?

A complete characterization of the photometry of our large pavement sample panel was conducted at the initial state and after an outdoor aging of 30 months. It was thus possible to conduct lighting simulations with two considered practical cases of relamping. The quality of the lighting obtained is analyzed by comparison with the criteria defined in (EN 13201-2, 2015).

The paper is organized as follows. In the first methodology part, we recall the basics of road lighting and describe our selection of pavements, our aging and measurement protocol and the lighting calculation methodology. In the second part, the results of the study regarding road surface photometry are given and discussed comparing stabilized and initial photometry. The third part presents the results of the lighting calculations conducted after the stabilisation of the pavement photometry and the impact at the initial stage.

\section{Methodology}

\subsection{Road lighting basics}

The surface of a pavement is classified according to its reflection properties (CIE 144, 2001). The most characteristic parameter is the luminance coefficient $q$, given as:

$$
q(\beta, \gamma)=L(\beta, \gamma) /\left(E_{h}\right)
$$

It is the ratio between the observed luminance $L$ in $\mathrm{cd} . \mathrm{m}^{-2}$ which the observer sees, and the illuminance $E_{\mathrm{h}}$ in lux which is incident on the surface (Figure 1).

The standardised viewing height is $1.5 \mathrm{~m}$ and the angle of observation $\alpha$ is constant at $1^{\circ}$, corresponding to an observation distance of $86 \mathrm{~m}$. The lighting standards use the area of the road between $60 \mathrm{~m}$ and $160 \mathrm{~m}$ ahead of the driver, because it is considered an important area for the detection of obstacles. It was also defined for interurban driving where the speed is about 80 to $90 \mathrm{~km} / \mathrm{h}$. Since the 1980s, for practical reasons the luminance coefficient was replaced by the reduced luminance coefficient $r$ in $\mathrm{cd} \cdot \mathrm{m}^{2}$.lux ${ }^{-1}$, which is derived from $q$ :

\footnotetext{
* AITF (Association des Ingénieurs Territoriaux de France),

** AFE (Association Française de l'Eclairage),

Office des Asphaltes, ROUTES DE FRANCE, SPECBEA (Spécialistes de la Chaussée en Béton Et des Aménagements), CIMbéton (Centre d'information sur le ciment et ses applications), EUROBITUME

$\perp$ Cerema (Centre d'Etudes et d'expertise sur les Risques, l'Environnement, la Mobilité et l'Aménagement), CERIB (Centre d'Etudes et de Recherches de l'Industrie du Béton), CTMNC (Centre Technique des Matériaux Naturels de Construction).
} 


$$
r(\beta, \gamma)=10^{4} \times q(\beta, \gamma) \times \cos ^{3} \gamma
$$

A reduced coefficient table called $r$-table was defined, where the luminance coefficient $r$ is given for a combination of fixed lighting angles $\beta$ and $\tan \varepsilon$. The average luminance coefficient $Q_{0}$, represents the degree of lightness of the measured surface. It is computed as the average of the luminance coefficients over the specified solid angle, $\Omega_{0}$. The specular factor $S_{1}$ represents the degree of specularity (shininess) of the observed surface. It is defined as the ratio between the reduced luminance coefficients of two specific illumination conditions.

$$
Q_{0}=\frac{1}{\Omega_{0}} \int q \mathrm{~d} \Omega
$$

$$
S_{1}=\frac{r(\beta=0, \tan \varepsilon=2)}{r(\beta=0, \tan \varepsilon=0)}
$$
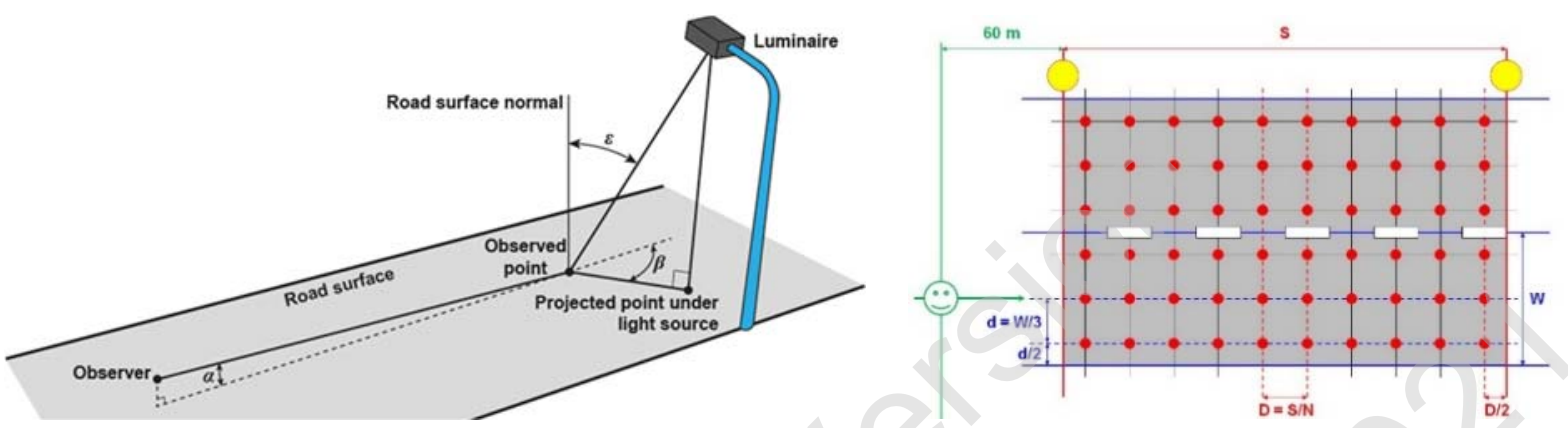

Figure 1 - (left) The photometric characteristics of the road surface depend on the angles of observation $\alpha$, deviation $\beta$ and incidence $\varepsilon$. (right) Example of a calculation /measurement grid points (in red) in road lighting design/evaluation, according to the standard ( $w$ is the traffic lane width, $d$ the transversal distance between two lines of points and $D$ the longitudinal distance between two columns of points).

The CIE has defined different set of standard $r$-tables that are directly available in all lighting design software(CIE 066, 1984). Since 2001, the CIE (CIE 144, 2001) recommends a scaling of the chosen standard table according to the average luminance coefficient parameters $Q_{0}$. It is obvious that the design of a road lighting system should be based on the knowledge of the actual luminance coefficient for the actual road. Because the actual quantity of $q$ is not known, nor is listed as reference values in the EN standard (it provides only the directions in which $q$ should be known), designers use in the calculations as $q$ reference values the ones given in CIE 144 scientific publication. In France the CIE $r$-tables type $\mathrm{R}$ are mostly used.

Guidelines and road lighting standards in Europe give values for illuminance and luminance and their distribution on the road surface according to a grid of points whose number $N$ depends on the pole spacing $S$ and number of traffic lanes (Figure 1 right). The standard road lighting quality criteria (EN 13201-2, 2015, EN 13201-3, 2015) are derived from the luminance calculated on the grid which are:

- The average luminance $L_{\text {ave }}$, as the arithmetic average of the luminance calculated on each point of the grid;

- Overall uniformity of luminance $U_{0}$, as the ratio of the minimum luminance to the average luminance of the whole grid;

- Lengthwise uniformity of luminance $U_{l}$, as the ratio of the minimum luminance to the maximum luminance along the axis of each driving lane;

- Threshold Increment $f_{T l}$, as the measure of the disability glare;

- Edge Illuminance Ratio $R_{E I}$, as the ratio of the illuminance on a strip adjacent to the road, to the illuminance on the same strip lying on the adjacent driving lane.

The luminance is calculated from the axis of each lane of the road, embracing the whole width of the grid. For luminance, uniformities and edge illuminance ratio, the lowest value from all lanes is operative. For threshold increment, the highest value is operative. 


\subsection{The choice and characterisation of the pavements}

\subsubsection{Methods}

The first step was to establish a representative panel of urban and interurban surfacing materials including innovative French technologies. This panel includes 38 different pavements:

- 11 asphaltic concrete (with bituminous or synthetic binder),

- 6 mastic asphalt (with bituminous or synthetic binder),

- 10 poured cement concrete,

- 7 precast cement concrete paving blocks,

- 4 natural stones sett paving.

For each type of pavement, several parameters have been differentiated in order to represent both conventional and innovative pavements used in cities. In particular, the following parameters were variable, depending of materials:

- Formulation: nature and percentage of binder, aggregates granulometry, porosity,

- Poured or precast material,

- Aggregates colour: dark, clear depending of the colour of the used stones,

- Surface treatment: raw pavements, sandblasted, broomed, etc.

Their $r$-tables were measured with the Cerema laboratory gonioreflectometer (Figure 2 ) in order to evaluate their photometric properties (Muzet, 2019). All the pavements were measured at their initial state (called T0) and then installed outside in order to undergo a natural ageing during 30 months (called T30). This ageing implies sun, rain and any other weather condition exposition but not any mechanical influence such as traffic. The ageing applied corresponds to what could be observed on both the central lanes of roads and on urban pavements not used by cars, such as cycle paths, sideways or squares. Nearly all of them except natural stones were measured after 30 months of natural aging.
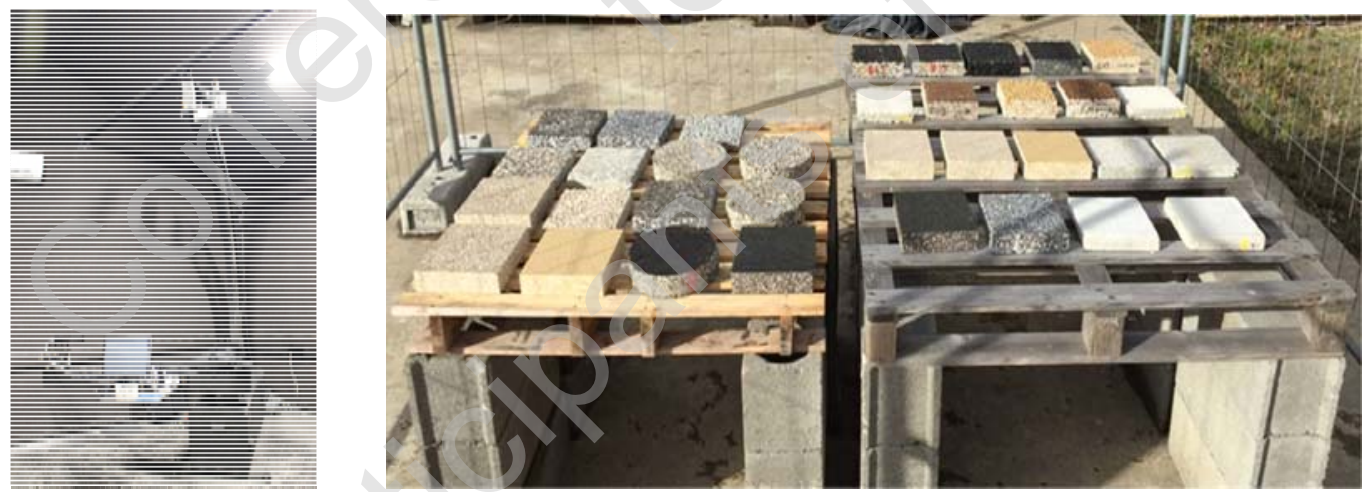

Figure 2 - Pictures of the Cerema gonioreflectometer (left), and of the samples outdoor during natural ageing (right)

For the lighting simulation, seven pavements with light aggregates were selected to test the calculation methodology. Their picture is in the Figure 5 and their characteristics are the following (a short name used afterwards is indicated in brackets):

- Raw very thin asphaltic concrete, clear aggregates size 0/6mm (Raw Asphaltic Concrete)

- Sandblasted very thin asphaltic concrete, clear aggregates size $0 / 6 \mathrm{~mm}$ (Sandblasted Asphaltic Concrete),

- Raw asphaltic concrete, synthetic binder, clear aggregates size 0/10 mm $+\mathrm{TiO}_{2}$ adding's (Raw Synthetic Asphaltic Concrete),

- Bush hammered poured cement concrete, clear aggregates size 0/14 mm (Bush hammered Cement Concrete), 
- Draining cement poured concrete, clear aggregates size 4/10 mm (Draining cement concrete),

- Shotblasted soft mastic asphalt, clear aggregates size 0/10 mm (Shotblasted mastic asphalt),

- Shotblasted soft mastic asphalt, synthetic binder clear aggregates size $0 / 10 \mathrm{~mm}+\mathrm{TiO}_{2}$ adding's (Shotblasted synthetic mastic asphalt).

\subsection{The lighting simulations}

The second step consisted in conducting lighting simulations, with a representative set of street lighting distributions. The quality of the lighting is analyzed using the criteria defined in the EN 13201 standard (EN 13201-2, 2015, EN 13201-3, 2015). For all our analysis we chose the $\mathrm{CIE}$ reference table R3 to make the comparison because it is the most used in France and one of the most used with C2 worldwide (Gidlund, 2019).

Two cases are considered:

1. Case of the classical relamping of a lighting installation where the geometry is imposed and the pavement used for the lighting design remains the standard CIE R3. The luminaire configuration is optimized on this R3 pavement, to minimize the installed power. The quality of the lighting is then computed again, with the same luminaire configuration, taking into account the actual measured $r$-table when it is new (T0) and after 30 months (T30).

2. Case of the relamping of a lighting installation where the geometry is imposed and the pavement used for the lighting design is the actual stabilized pavement measured at T30. For each pavement, the luminaire configuration is independently optimized to minimize the installed power. The quality of the lighting is then recalculated with the same luminaire configuration, on the same pavement at its initial state (T0). Comparison are conducted with the CIE R3 table.

The lighting simulations are performed on two road profiles:

1. An urban avenue composed of four driving lanes, illuminated by a bilateral lighting installation compliant with a M2 lighting class $\left(L_{\text {ave }} \geq 1.5 \mathrm{~cd} / \mathrm{m}^{2}, U_{0} \geq 40 \%, U_{l} \geq 70 \%\right.$, $f_{T I} \leq 10 \%, R_{E I} \geq 30 \%$ ).

2. A residential street composed of two driving lanes, illuminated by a single-sided lighting installation compliant with a M4 lighting class (Lave $\geq 0.75 \mathrm{~cd} / \mathrm{m}^{2}, U_{0} \geq 40 \%, U_{1} \geq 60 \%$, $\left.f_{T I} \leq 15 \%, R_{E I} \geq 30 \%\right)$.
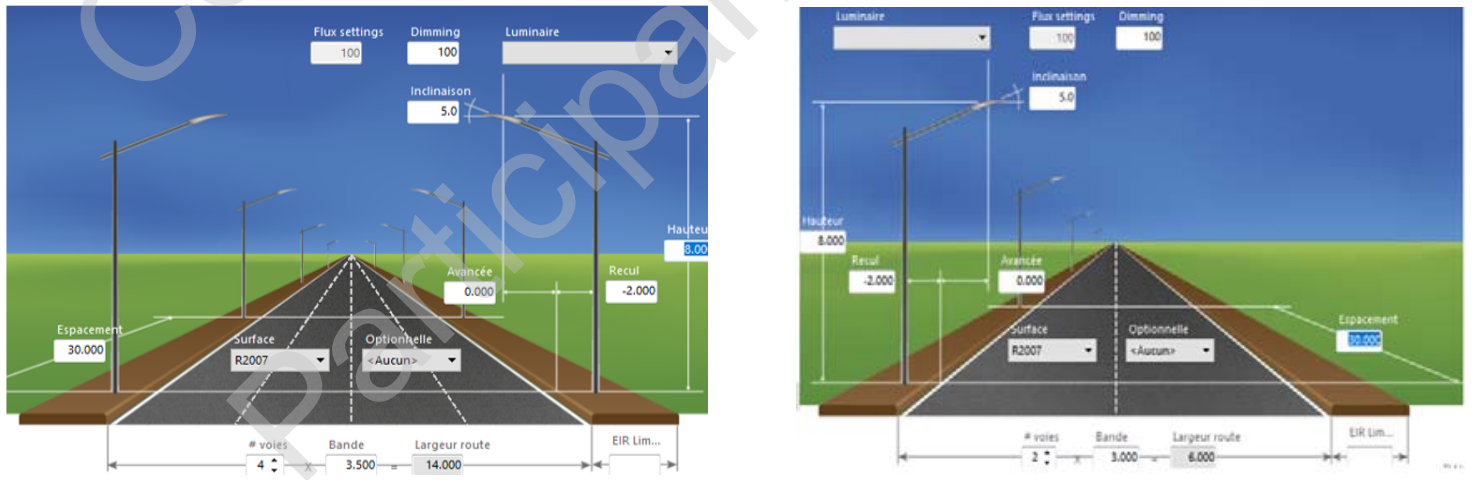

Figure 3 - Representation of the two road profiles: Urban avenue, bilateral opposition (left), Residential street, single-sided (right).

\section{Results}

\subsection{Photometric measurements of urban pavements}

The graph of the Figure 4 presents the evolution of $Q_{0}$ and $S_{1}$ parameters during aging for each sample, the origin of the arrow is the T0 measurement and the arrowhead is the T30 measurement. 

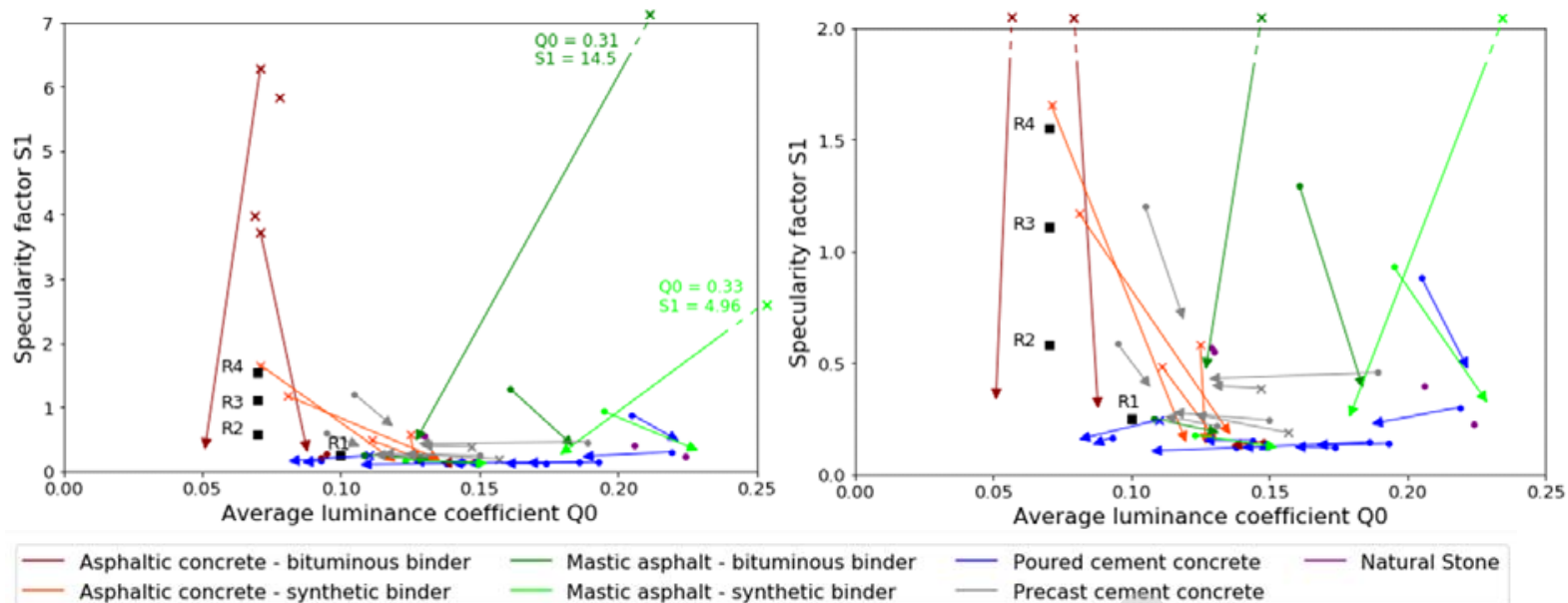

Figure 4 - Representation of the P\&L photometric measurements $\left(S_{1}\right.$ and $\left.Q_{0}\right)$ for all the pavements. Focus for specularity under $2\left(S_{1}<2.0\right)$ on the right figure.

The initial state TO is presented with crosses for raw pavements and circles for the others. The T30 measurement corresponds to the arrowheads. The asphaltic concretes are in red and orange, the mastic asphalts in green, the poured cement concrete in blue, the precast cement concrete in grey and the natural stones in violet. The reference CIE r-tables are also presented in black squares.

The characteristics of the seven pavements selected for the lighting simulation are presented in Figure 5 with pictures, $Q_{0}$ coefficient, $S_{1}$ factor and the corresponding photometric solid at T0 and T30 states.

The results of the photometric measurements of the pavements in their new condition at T0 confirm that there is an enormous diversity of behaviours (Figure 4). After 30 months, the variety fades a little but remains very significant. These results confirm again that the CIE standard tables do not reflect the diversity of all pavements (Dumont, 2007, Gidlund, 2019).

In the Figure 4, almost all the arrows are oriented downwards, which means that there is a drop in specularity with time on the vast majority of pavements. This evolution is really important for the raw asphaltic pavements (concrete and mastic) which were initially very specular but remains more moderate or even negligible for cement concrete samples (both poured and precast). These results are in accordance with previous results (Dumont, 2007, Muzet, 2018, Muzet, 2019a). Binder mainly explains this evolution. Indeed, bitumen is very shiny and specular at its initial state and evolves really fast. On the other hand, cement has a diffuse aspect almost from the beginning. The synthetic binder has an intermediate behaviour with an initial state more specular than cement but much less than bitumen.

After 30 months, 4 samples are CIE R2 type and all the 26 others are classified as CIE R1 type, mainly due to this specularity evolution. Such low values of specularity are not usually measured on conventional circulated road surfaces (Dumont, 2007, Gidlund, 2019) but it was shown in (Jackett, 2009) that non circulated pavements were more diffuse after aging than the ones exposed to traffic.

The evolution with time of the average luminance coefficient $Q_{0}$ also differs depending on the pavement surface material. Except for initially very specular surfaces, for the asphaltic concrete and mastic asphalt samples, the luminance coefficient increased between T0 and T30. In accordance with the samples visual evolution (figure 5), a general explanation could be that ageing with meteorological condition has a kind of tarnishing effect on these samples, slightly lightening their surface. On the contrary, the luminance coefficient of cement concrete almost systematically slightly decreased. Since the surface of these samples was quite light from the start, ageing seems to darken them slightly, which is rather confirmed by the visual evolution. As above, this behaviour is not observed when the T0 samples were more specular. 


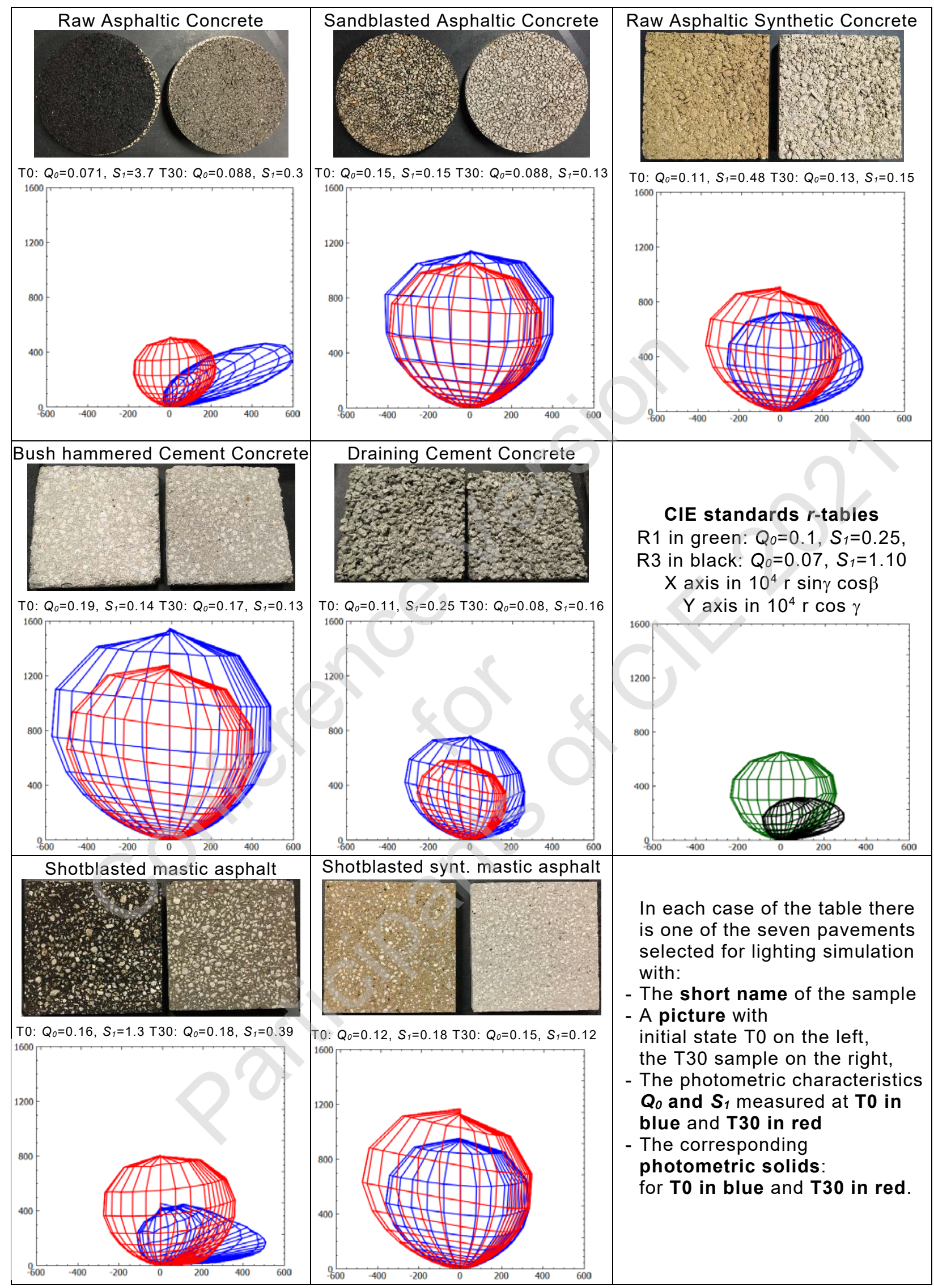

Figure 5 - The seven pavements selected for the lighting simulation - Pavement name, surface aspect (pictures) and photometric characterization $\left(Q_{0}, S_{1}\right.$ and solid) evolution from its initial state (T0) and after 30 months of natural outdoor aging (T30). 


\subsection{The lighting simulations}

\subsubsection{Case 1 - Relamping with CIE pavement}

In case 1 of the lighting simulations, the LED relamping is designed with the standard R3 CIE table. The corresponding lighting criteria obtained with the different pavements at their initial and stabilized state is presented in the table 1 for the bilateral avenue profile and in the table 2 for the residential street profile.

Table 1 - Case 1 Relamping with an optimisation for the $r$-table R3 - Profile 1 Urban avenue. Results on the stabilised pavement (T30) in bold and on the new pavement (TO).

\begin{tabular}{|c|c|c|c|c|c|c|c|c|c|c|c|c|c|}
\hline \multicolumn{4}{|l|}{ Pavement } & & \multicolumn{6}{|c|}{ Luminance } & \multicolumn{2}{|c|}{ Glare TI } & \multirow[b]{2}{*}{$\begin{array}{l}\text { Standard } \\
\text { conformity }\end{array}$} \\
\hline Name & Age & Q0 & S1 & $\begin{array}{l}\text { CIE } \\
\text { class }\end{array}$ & \begin{tabular}{|c|} 
Lmoy $\geq$ \\
1,50 \\
$\mathrm{~cd} / \mathrm{m}^{2}$
\end{tabular} & $\begin{array}{c}\text { DELTA } \\
\text { Lmoy } \\
\text { /standard }\end{array}$ & $\begin{array}{l}\text { Uo } \geq \\
40 \%\end{array}$ & $\begin{array}{c}\text { DELTA Uo } \\
\text { / standard }\end{array}$ & $\begin{array}{c}\mathrm{UI} \geq 70 \\
\%\end{array}$ & $\begin{array}{c}\text { DELTA UL / } \\
\text { standard }\end{array}$ & $\begin{array}{c}\text { TI } \leq 10 \\
\%\end{array}$ & $\begin{array}{l}\text { DELTA TI / } \\
\text { standard }\end{array}$ & \\
\hline CIE R3 table - Reference & - & 0.07 & 1.11 & R3 & 1.50 & $0 \%$ & 59 & $47 \%$ & 80 & $14 \%$ & 10 & $-1 \%$ & OK \\
\hline Raw Asphaltic Concrete & T30 & 0.088 & 0.295 & R1 & 1.71 & $14 \%$ & 71 & $76 \%$ & 57 & $-18 \%$ & 9 & $-11 \%$ & NOK \\
\hline Raw Asphaltic Concrete & TO & 0.071 & 3.74 & R4 & 1.77 & $18 \%$ & 43 & $7 \%$ & 57 & $-19 \%$ & 9 & $-13 \%$ & NOK \\
\hline Sandblasted Asphaltic Concrete & T30 & 0.136 & 0.128 & R1 & 2.77 & $85 \%$ & 63 & $56 \%$ & 43 & $-38 \%$ & 6 & $-39 \%$ & NOK \\
\hline Sandblasted Asphaltic Concrete & T0 & 0.148 & 0.148 & R1 & 3.06 & $104 \%$ & 63 & $57 \%$ & 44 & $-37 \%$ & 6 & $-44 \%$ & NOK \\
\hline Raw Synthetic asphaltic Concrete & T30 & 0.131 & 0.153 & R1 & 2.62 & $74 \%$ & 66 & $64 \%$ & 48 & $-31 \%$ & 6 & $-37 \%$ & NOK \\
\hline Raw Synthetic asphaltic Concrete & TO & 0.111 & 0.484 & R2 & 2.45 & $63 \%$ & 62 & $54 \%$ & 65 & $-7 \%$ & 7 & $-33 \%$ & NOK \\
\hline Bush hammered Cement Concrete & T30 & 0.167 & 0.132 & R1 & 3.41 & $127 \%$ & 63 & $58 \%$ & 44 & $-37 \%$ & 5 & $-49 \%$ & NOK \\
\hline Bush hammered Cement Concrete & TO & 0.193 & 0.14 & R1 & 3.98 & $166 \%$ & 63 & $59 \%$ & 44 & $-37 \%$ & 5 & $-55 \%$ & NOK \\
\hline Draining cement concrete & T30 & 0.081 & 0.157 & R1 & 1.70 & $13 \%$ & 68 & $70 \%$ & 50 & $-29 \%$ & 9 & $-10 \%$ & NOK \\
\hline Draining cement concrete & TO & 0.11 & 0.245 & R1 & 2.44 & $63 \%$ & 62 & $54 \%$ & 59 & $-16 \%$ & 7 & $-33 \%$ & NOK \\
\hline Shotblasted mastic asphalt & $\mathrm{T} 30$ & 0.184 & 0.386 & R1 & 3.15 & $110 \%$ & 71 & $76 \%$ & 60 & $-14 \%$ & 5 & $-45 \%$ & NOK \\
\hline Shotblasted mastic asphalt & TO & 0.161 & 1.29 & R3 & 2.71 & $80 \%$ & 57 & $42 \%$ & 75 & $7 \%$ & 6 & $-38 \%$ & $\mathrm{OK}$ \\
\hline Shotblasted synthetic mastic asphalt & $\mathrm{T} 30$ & 0.153 & 0.122 & R1 & 3.14 & $109 \%$ & 63 & $57 \%$ & 44 & $-37 \%$ & 5 & $-45 \%$ & NOK \\
\hline Shotblasted synthetic mastic asphalt & TO & 0.123 & 0.177 & $R 1$ & 2.59 & $72 \%$ & 69 & $71 \%$ & 49 & $-30 \%$ & 6 & $-36 \%$ & NOK \\
\hline
\end{tabular}

Table 2 - Case 1 Relamping with an optimisation for the $r$-table R3 - Profile 2 Residential street. Results on stabilised pavement (T30) and on new pavement (TO).

\begin{tabular}{|c|c|c|c|c|c|c|c|c|c|c|c|c|c|}
\hline \multicolumn{5}{|c|}{ Pavement } & \multicolumn{6}{|c|}{ Luminance } & \multicolumn{2}{|c|}{ Glare TI } & \multirow[b]{2}{*}{$\begin{array}{l}\text { Standard } \\
\text { conformity }\end{array}$} \\
\hline Name & Age & Q0 & S1 & $\begin{array}{l}\text { CIE } \\
\text { class }\end{array}$ & $\begin{array}{c}\text { Lmoy } \geq 0,75 \\
\mathrm{~cd} / \mathrm{m}^{2}\end{array}$ & $\begin{array}{l}\text { DELTA Lmoy } \\
\text { /standard }\end{array}$ & $\begin{array}{c}\text { Uo } \geq 40 \\
\%\end{array}$ & \begin{tabular}{|l|} 
DELTA Uo \\
/ standard \\
\end{tabular} & $\mathrm{UI} \geq 60 \%$ & $\begin{array}{l}\text { DELTA UL / } \\
\text { standard }\end{array}$ & $\mathrm{TI} \leq 10 \%$ & \begin{tabular}{|c|} 
DELTA TI / \\
standard \\
\end{tabular} & \\
\hline Reference: CIE R3 table & - & 0.07 & 1.11 & R3 & 0.75 & $0 \%$ & 57 & $43 \%$ & 80 & $84 \%$ & 10 & $-1 \%$ & OK \\
\hline \multirow{2}{*}{ Raw Asphaltic Concrete } & T30 & 0.088 & 0.30 & R1 & 0.85 & $14 \%$ & 67 & $68 \%$ & 58 & $-4 \%$ & 10 & $-34 \%$ & NOK \\
\hline & TO & 0.071 & 3.74 & R4 & 0.91 & $21 \%$ & 39 & $-1 \%$ & 52 & $-13 \%$ & 9 & $-43 \%$ & NOK \\
\hline \multirow{2}{*}{$\begin{array}{c}\text { Sandblasted Asphaltic } \\
\text { Concrete }\end{array}$} & T30 & 0.136 & 0.13 & R1 & 1.40 & $86 \%$ & 57 & $42 \%$ & 43 & $-28 \%$ & 7 & $-55 \%$ & NOK \\
\hline & TO & 0.148 & 0.15 & $\mathrm{R} 1$ & 1.54 & $105 \%$ & 57 & $43 \%$ & 44 & $-26 \%$ & 6 & $-59 \%$ & NOK \\
\hline \multirow{2}{*}{$\begin{array}{c}\text { Raw Synthetic } \\
\text { asphaltic Concrete }\end{array}$} & 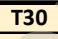 & 0.131 & 0.15 & R1 & 1.31 & $75 \%$ & 60 & $\overline{51 \%}$ & 48 & -19\% & 7 & $-53 \%$ & NNOK \\
\hline & T0 & 0.111 & 0.48 & R2 & 1.25 & $66 \%$ & 59 & $48 \%$ & 73 & $21 \%$ & 7 & $-52 \%$ & NOK \\
\hline \multirow{2}{*}{$\begin{array}{l}\text { Bush hammered } \\
\text { Cement Concrete }\end{array}$} & T30 & 0.167 & 0.13 & R1 & 1.72 & $129 \%$ & 58 & "44\% & 44 & $-26 \%$ & 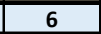 & $-62 \%$ & NOK \\
\hline & TO & 0.193 & 0.14 & R1 & 2.00 & $167 \%$ & 59 & $47 \%$ & 44 & $-27 \%$ & 5 & $-66 \%$ & NOK \\
\hline \multirow{2}{*}{$\begin{array}{l}\text { Draining cement } \\
\text { concrete }\end{array}$} & T30 & 0.081 & 0.16 & R1 & 0.86 & $15 \%$ & 60 & $51 \%$ & 50 & $-16 \%$ & 10 & $-34 \%$ & NOK \\
\hline & T0 & 0.11 & 0.25 & R1 & 1.26 & $68 \%$ & 60 & $50 \%$ & 63 & $6 \%$ & 7 & $-52 \%$ & $\mathrm{OK}$ \\
\hline \multirow{2}{*}{$\begin{array}{c}\text { Shotblasted mastic } \\
\text { asphalt }\end{array}$} & T30 & 0.184 & 0.39 & R1 & 1.56 & $108 \%$ & 67 & $67 \%$ & 61 & $1 \%$ & 6 & $-60 \%$ & OK \\
\hline & TO & 0.161 & 1.29 & R3 & 1.33 & $78 \%$ & 54 & $36 \%$ & 73 & $22 \%$ & 6 & $-58 \%$ & OK \\
\hline \multirow{2}{*}{$\begin{array}{l}\text { Shotblasted synt. } \\
\text { mastic asphalt }\end{array}$} & T30 & 0.153 & 0.12 & R1 & 1.58 & $111 \%$ & 58 & $44 \%$ & 44 & $-27 \%$ & 6 & $-59 \%$ & NOK \\
\hline & T0 & 0.123 & 0.18 & $R 1$ & 1.31 & $75 \%$ & 65 & $62 \%$ & 49 & $-18 \%$ & 7 & $-53 \%$ & NOK \\
\hline
\end{tabular}

When the actual photometry of the different type of pavements is integrated into the simulation to calculate the lighting quality criteria, the requirements of the standard are rarely met for the pavements in their initial state (TO). With the measurements carried out in the stabilised condition (T30), there is still a high proportion of non-compliant photometric results. When the actual pavement is not taken into account for the design, the results on the two road profiles show that the most sensitive parameter is the longitudinal uniformities. This poor longitudinal uniformity results in alternating dark and light stripes and can cause safety problems.

The higher values of average luminance on the actual pavements are a consequence of their $Q_{0}$ values, which are $14 \%$ to $270 \%$ higher than the standard $Q_{0}$ value associated to R3 $(0.07)$. This shows a potential to reduce the required luminous flux, and therefore the installed power, provided that a suitable light distribution can be used such as to provide compliant uniformities on the actual pavements. 


\subsubsection{Case 2 - Relamping with actual pavement}

In case 2 of the lighting simulations, the LED relamping is designed while taking into account the actual stabilised $r$-table of each measured pavements (T30). The results of lighting optimisation at T30 are presented in the table 3 for the bilateral avenue profile and in the table 4 for the residential street profile.

When taking into account the actual stabilized pavements (T30) to achieve the lighting design, it is possible to find compliant results with all pavements for the two profiles. This allows to optimize the luminous flux required and therefore the installed power. Power savings of $50 \%$ to $60 \%$ are possible, within the first set of light pavements presently considered.

Table 3 - Case 2 Relamping with an optimisation on T30 actual pavements - Profile 1 Urban avenue with bilateral lighting. Results for the seven selected pavements at their stabilized state T30 (in bold) and at TO.

\begin{tabular}{|c|c|c|c|c|c|c|c|c|c|c|c|c|c|c|c|c|}
\hline \multicolumn{5}{|c|}{ Pavements } & \multicolumn{6}{|c|}{ Luminance } & \multicolumn{2}{|c|}{ Glare } & \multicolumn{3}{|c|}{ Energy aspect } & \multirow[b]{2}{*}{$\begin{array}{l}\text { Standard } \\
\text { conformity }\end{array}$} \\
\hline Name & Age & Q0 & s1 & $\begin{array}{c}\text { CIE } \\
\text { class }\end{array}$ & $\begin{array}{c}\text { Lmoy } \geq \\
1,50 \mathrm{~cd} / \mathrm{m}^{2}\end{array}$ & $\begin{array}{l}\text { DELTA } \\
\text { Lmoy / } \\
\text { standard }\end{array}$ & $\begin{array}{c}\text { Uo } \geq 40 \\
\%\end{array}$ & $\begin{array}{l}\text { DELTA Uo } \\
\text { / standard }\end{array}$ & $\begin{array}{l}\mathrm{UI} \geq 70 \\
\%\end{array}$ & $\begin{array}{l}\text { DELTA UL } \\
\text { / standard }\end{array}$ & $\begin{array}{c}T \mid \leq 10 \\
\%\end{array}$ & $\begin{array}{c}\text { DELTA } \\
\text { TI/ } \\
\text { standard }\end{array}$ & $\begin{array}{l}\text { Lamp } \\
\text { power } \\
\text { (W) }\end{array}$ & $\mathrm{kwh} / \mathrm{km}$ & \begin{tabular}{|l} 
Power \\
saving / \\
R3 Ref.
\end{tabular} & \\
\hline CIE R3 table - Reference & - & 0.07 & 1.1 & R3 & 1.52 & $1 \%$ & 59 & $47 \%$ & 80 & $14 \%$ & 10 & $-1 \%$ & 51.2 & 3.48 & & OK \\
\hline Raw Asphaltic Concrete & T30 & 0.088 & 0.3 & R1 & 1.52 & $1 \%$ & 62 & $54 \%$ & 71 & $2 \%$ & 8 & $-20 \%$ & 46.1 & 3.14 & $-10 \%$ & OK \\
\hline Raw Asphaltic Concrete & TO & 0.071 & 3.7 & R4 & 1.35 & $-10 \%$ & 41 & $3 \%$ & 43 & $-39 \%$ & 9 & $-13 \%$ & 46.1 & 3.14 & $-10 \%$ & NOK \\
\hline Sandblasted Asphaltic Concrete & T30 & 0.136 & 0.1 & R1 & 1.52 & $1 \%$ & 66 & $64 \%$ & 77 & $10 \%$ & 5 & $-54 \%$ & 28.7 & 1.95 & $-44 \%$ & OK \\
\hline Sandblasted Asphaltic Concrete & TO & 0.148 & 0.1 & R1 & 1.67 & $11 \%$ & 67 & $67 \%$ & 79 & $14 \%$ & 4 & $-57 \%$ & 28.7 & 1.95 & $-44 \%$ & OK \\
\hline Raw Synthetic asphaltic Concrete & T30 & 0.131 & 0.2 & R1 & 1.53 & $2 \%$ & 75 & $87 \%$ & $\overline{74}$ & $5 \%$ & 8 & $-19 \%$ & 30.9 & 2.10 & $-40 \%$ & OK \\
\hline Raw Synthetic asphaltic Concrete & TO & 0.111 & 0.5 & R2 & 1.34 & $-11 \%$ & 76 & $90 \%$ & 79 & $12 \%$ & 9 & $-10 \%$ & 30.9 & 2.10 & $-40 \%$ & NOK \\
\hline Bush hammered Cement Concrete & T30 & 0.167 & 0.1 & R1 & 1.55 & $3 \%$ & 72 & $81 \%$ & 70 & $-1 \%$ & 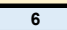 & $-36 \%$ & 24.6 & 1.67 & $-52 \%$ & OK \\
\hline Bush hammered Cement Concrete & TO & 0.193 & 0.1 & R1 & 1.81 & $21 \%$ & 72 & $81 \%$ & 69 & $-1 \%$ & 6 & $-44 \%$ & 24.6 & 1.67 & $-52 \%$ & NOK \\
\hline Draining cement concrete & $\overline{T 30}$ & 0.081 & 0.2 & R1 & 1.56 & $4 \%$ & 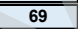 & $73 \%$ & 70 & $0 \%$ & 8 & $-21 \%$ & 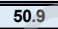 & 3.46 & $-1 \%$ & OK \\
\hline Draining cement concrete & TO & 0.11 & 0.2 & R1 & 2.13 & $42 \%$ & 72 & $80 \%$ & 69 & $-1 \%$ & 6 & $-38 \%$ & 50.9 & 3.46 & $-1 \%$ & NOK \\
\hline Shotblasted mastic asphalt & 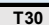 & 0.184 & $\overline{0.4}$ & R1 & 1.54 & $3 \%$ & 48 & $20 \%$ & 74 & $5 \%$ & 9 & $-13 \%$ & 23.5 & $\overline{1.60}$ & $-54 \%$ & OK \\
\hline Shotblasted mastic asphalt & TO & 0.161 & 1.3 & R3 & 1.41 & $-6 \%$ & 32 & $-19 \%$ & 65 & $-7 \%$ & 9 & $-6 \%$ & 23.5 & 1.60 & $-54 \%$ & NOK \\
\hline Shotblasted Synt. mastic asphalt & T30 & 0.153 & 0.1 & R1 & 1.53 & $2 \%$ & 73 & $82 \%$ & 71 & $1 \%$ & 7 & $-32 \%$ & 26.1 & 1.78 & $-49 \%$ & OK \\
\hline Shotblasted Synt. mastic asphalt & T0 & 0.123 & 0.2 & R1 & 1.24 & $-18 \%$ & 74 & $85 \%$ & 73 & $4 \%$ & 8 & $-19 \%$ & 26.1 & 1.78 & $-49 \%$ & NOK \\
\hline
\end{tabular}

Table 4 - Case 2 Relamping with an optimisation on T30 actual pavements - Profile 2

Residential street. Results for the seven selected pavements at their stabilized state T30 (in bold) and at TO.

\begin{tabular}{|c|c|c|c|c|c|c|c|c|c|c|c|c|c|c|c|c|}
\hline \multicolumn{5}{|c|}{ Pavements } & \multicolumn{4}{|c|}{ Luminance } & \multicolumn{2}{|r|}{ 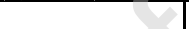 } & \multicolumn{2}{|c|}{ Glare } & \multicolumn{3}{|c|}{ Energy aspects } & \multirow[b]{2}{*}{$\begin{array}{l}\text { Standard } \\
\text { Conformity }\end{array}$} \\
\hline Name & Age & Q0 & s1 & $\begin{array}{l}\mathrm{CIE} \\
\text { class }\end{array}$ & $\begin{array}{l}\operatorname{Lmoy} \geq \\
0.75 \mathrm{~cd} / \mathrm{m}^{2}\end{array}$ & $\begin{array}{c}\text { Delta } \\
\text { Lmoy/ } \\
\text { standard }\end{array}$ & Uo $\geq 40 \%$ & $\begin{array}{l}\text { Deita Uo I } \\
\text { standard }\end{array}$ & $\mathrm{UI} \geq 60 \%$ & $\begin{array}{l}\text { Delta UI I } \\
\text { standard }\end{array}$ & $\mathrm{TI} \leq 10 \%$ & $\begin{array}{l}\text { Delta TI / } \\
\text { standard }\end{array}$ & $\begin{array}{c}\text { Lamp } \\
\text { power (W) }\end{array}$ & $\mathrm{kwh} / \mathrm{km}$ & $\begin{array}{l}\text { Power } \\
\text { saving / } \\
\text { R3 Ref. }\end{array}$ & \\
\hline $\begin{array}{c}\text { Reference: CIE R3 } \\
\text { table }\end{array}$ & - & 0.07 & 1.11 & 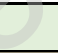 & 0.75 & $0 \%$ & 57 & $44 \%$ & 84 & $39 \%$ & 10 & $-31 \%$ & 28.6 & 0.97 & & OK \\
\hline \multirow{2}{*}{$\begin{array}{c}\text { Raw Asphaltic } \\
\text { Concrete }\end{array}$} & T30 & 0.088 & 0.30 & R1 & 0.75 & $0 \%$ & 52 & $29 \%$ & 67 & $12 \%$ & 13 & $-15 \%$ & 25.0 & 0.85 & $-13 \%$ & OK \\
\hline & TO & 0.071 & 3.74 & $\mathrm{R} 4$ & 0.84 & $12 \%$ & 25 & $-38 \%$ & 48 & $-21 \%$ & 9 & $-40 \%$ & 25.0 & 0.85 & $-13 \%$ & NOK \\
\hline \multirow{2}{*}{$\begin{array}{l}\text { Sandblasted Asphaltic } \\
\text { Concrete }\end{array}$} & $\bar{T} \mathbf{T 3 0}$ & 0.136 & 0.13 & R1 & 0.77 & $2 \%$ & 47 & $18 \%$ & 61 & $2 \%$ & 10 & $-34 \%$ & 13.6 & 0.46 & $-53 \%$ & OK \\
\hline & TO & 0.148 & 0.15 & R1 & 0.85 & $13 \%$ & 46 & $16 \%$ & 62 & $3 \%$ & 7 & $-54 \%$ & 13.6 & 0.46 & $-53 \%$ & OK \\
\hline \multirow{2}{*}{$\begin{array}{c}\text { Raw Synthetic } \\
\text { asphaltic Concrete } \\
\end{array}$} & $\bar{T} \mathbf{T} 30$ & 0.131 & 0.15 & R1 & 0.75 & $0 \%$ & 51 & $26 \%$ & 67 & $12 \%$ & 8 & $-50 \%$ & 14.0 & 0.48 & $-51 \%$ & OK \\
\hline & TO & 0.111 & 0.48 & R2 & 0.75 & $0 \%$ & 41 & $2 \%$ & 84 & $40 \%$ & 8 & $-48 \%$ & 14.0 & 0.48 & $-51 \%$ & OK \\
\hline \multirow{2}{*}{$\begin{array}{l}\text { Bush hammered } \\
\text { Cement Concrete }\end{array}$} & T30 & 0.167 & 0.13 & R1 & 0.75 & $0 \%$ & 48 & $20 \%$ & 62 & $3 \%$ & 6 & $-60 \%$ & 10.7 & 0.37 & $-62 \%$ & OK \\
\hline & TO & 0.193 & 0.14 & R1 & 0.87 & $17 \%$ & 47 & $17 \%$ & 62 & $3 \%$ & 5 & $-64 \%$ & 10.7 & 0.37 & $-62 \%$ & OK \\
\hline \multirow{2}{*}{$\begin{array}{c}\begin{array}{c}\text { Draining cement } \\
\text { concrete }\end{array} \\
\end{array}$} & T30 & 0.081 & 0.16 & R1 & 0.76 & $1 \%$ & 49 & $22 \%$ & 66 & $11 \%$ & 12 & $-21 \%$ & 21.2 & 0.72 & $-26 \%$ & OK \\
\hline & TO & 0.11 & 0.25 & $\mathrm{R} 1$ & 1.14 & $52 \%$ & 42 & $5 \%$ & 72 & $20 \%$ & 9 & $-40 \%$ & 21.2 & 0.72 & $-26 \%$ & OK \\
\hline \multirow{2}{*}{$\begin{array}{c}\text { Shotblasted mastic } \\
\text { asphalt }\end{array}$} & $\mathrm{T} 30$ & 0.184 & 0.39 & R1 & 0.75 & $0 \%$ & 46 & $16 \%$ & 75 & $25 \%$ & 6 & $-58 \%$ & 11.1 & 0.38 & $-61 \%$ & OK \\
\hline & TO & 0.161 & 1.29 & R3 & 0.69 & $-7 \%$ & 34 & $-14 \%$ & 77 & $28 \%$ & 7 & $-56 \%$ & 11.0 & 0.37 & $-62 \%$ & NOK \\
\hline \multirow{2}{*}{$\begin{array}{l}\text { Shotblasted synthetic } \\
\text { mastic asphalt }\end{array}$} & T30 & 0.153 & 0.12 & R1 & 0.79 & $5 \%$ & 50 & $24 \%$ & 62 & $3 \%$ & 7 & $-56 \%$ & 12.3 & 0.42 & $-57 \%$ & OK \\
\hline & TO & 0.123 & 0.18 & $\mathrm{R} 1$ & 0.66 & $-12 \%$ & 47 & $17 \%$ & 68 & $14 \%$ & 8 & $-49 \%$ & 12.3 & 0.42 & $-57 \%$ & NOK \\
\hline
\end{tabular}

If we simulate the lighting quality for the corresponding new pavements at T0, the standard is not always fulfilled but the discrepancies with the limits are usually moderate. This is illustrated in the above tables, mostly due to insufficient values of overall and/or lengthwise uniformities of luminance. This seems typical of new pavements with a high degree of specularity, that decreases with ageing. For pavements with initial surface treatments, the standard is fulfilled at T30 and TO.

\section{Conclusions \& perspectives}

Our study has confirmed that the enormous range of photometric characteristics of current urban pavements cannot be described by the CIE standard tables (Dumont, 2007, Gidlund, 2019, Muzet, 2019a). Our panel of pavements includes both classic pavements and innovative pavements, even specific to urban environments. Some of these pavements were never characterized before as they are not used in interurban conditions where road photometry is mainly applied for now. The evolution over time differs greatly depending on the type of 
pavement and as already recommended in the (CIE 066, 1984) document, it is necessary to carry out lighting with stabilized characteristics (after 1 or 2 years of implementation).

We have shown that during the current relamping operations (case 1), the use of a typical CIE table leads to a non-compliance of the standard with risks of:

- strong over-lighting if the pavements in place are clear,

- bad to very bad uniformity which can lead to road safety problems.

With relamping based on an optimization on energetic aspect considering a stabilized pavement (case 2), all the specifications of the standard are met and thus the lighting installation complies with the safety of users. In addition, substantial savings can be made with clear coatings (up to $50 \%$ and $60 \%$ ). Finally, even if the pavement is new and the standard not fulfilled initially, the quality of the lighting is better than if the characteristics considered corresponds to a CIE standard pavement.

For our selection of pavements, the choice was made to consider rather light-coloured pavements that can allow energy savings. The results presented on this sample of pavements chosen to develop the calculation method should not be considered as qualifying the families of concretes, asphalts and others. Each of these families has a range of responses covering a wide range of performance in the optimization. Moreover, our traffic-free aging is relevant for urban pavements with little or no traffic but cannot be generalized to roads with high traffic.

The next steps are to make the calculations for our complete database of 38 pavements and also to make simulation for brand new installations, with lighting optimisation on lamp spacing considering both pavement and lighting photometry.

When a lighting installation is renewed, it is fundamental to take into account the pavement photometry. With the usual practice of considering a standard $r$-table, the EN 13201 criteria are generally not fulfilled, especially in terms of luminance uniformities. The diversity of photometry in today's pavements is huge and taking them into consideration can increase the quality of lighting and provide significant energy savings. Because of the possibility of having several optics in the luminaires, it will soon be possible to design adaptive luminaires that could adapt their photometry to the evolution of the existing coating. Knowing that the photometry of some pavements evolves very strongly in the first year (CIE 066, 1984, Dumont, 2007, Muzet, 2019), another solution is to apply an initial surface treatment to avoid the initial specularity and the first year uniformity problems.

With the constitution of a measurement database of actual pavements, this project will contribute to the CIE TC 4-50 (Road surface characterization for lighting applications) and work on EN 13201 standard.

\section{Aknowledgements and fundings}

We would like to thanks Joseph Abdo (CIMbéton), Frédérico Batista (CD 78), Salah Boussada (AITF/MEL), Brice Delaporte (Office des asphaltes), Jérôme Dherbecourt (Routes de France/EIFFAGE Routes), Thibaut Le Doeuff, Sophie Jacob, Lionel Monfront (CERIB), Florian Greffier (Cerema), Romain Lafon (Routes de France/EUROVIA), Christine Leroy (Routes de France), Emmanuel Loison (Routes de France/COLAS), Didier Pallix (CTMNC), Florence Pero (SPECBEA), Enoch Saint-Jacques (UGE).

This project received financial and/or intellectual support of the Pavements and Lighting group members. 


\section{References}

ABDO, J., BATISTA, F., CARRÉ, D., CHRISTORY, J.-P., DEPETRINJI, A., GANDON-LEGER, P., and PERET, M., 2010. Démarche innovante 'Revêtements et Lumière' de l'idée à la pratique". RGRA. 885, pp. 49-53. (in french).

CHAIN, C., LOPEZ, F., and VERNY, P., 2007. Impact of real road photometry on public lighting design. Presented at the CIE 26th Session, Beijing, China: CIE.

CHRISTORY, J.-P., BATISTA, F., GANDON-LEGER, P., and TALBOURDET, P., 2014. Pavements and light for the right lighting: contribution of concrete pavements. In: Eupave symposium on concrete roads, Praha, CZ

CIE 1984. CIE 066:1984. Road surfaces and lighting (joint technical report CIE/PIARC).

CIE 2001. CIE 144:2001. Road Surface and Road Marking Reflection Characteristics.

CIE 2019. CIE 140:2019. Road Lighting Calculations, 2nd Edition.

DUMONT, E., PAUMIER, J.L. 2007. Are standard tables R still representative of the properties of road surfaces in France? In: 26th session of the CIE, Beijing, China.

EN 13201-2:2015. Road lighting - Part 2: Performance requirements.

EN 13201-3:2015, Road lighting - Part 3: Calculation of performance.

GIDLUND, H., LINDGREN, M., MUZET, V., ROSSI, G., and IACOMUSSI, P., 2019. Road Surface Photometric Characterisation and Its Impact on Energy Savings. Coatings. 9 (5). https://doi.org/10.3390/coatings9050286

JACKETT, M. and FRITH, W., 2009. Measurement of the reflection properties of road surfaces to improve the safety and sustainability of road lighting. NZTA Research Report number 383. http://www.nzta.govt.nz/resources/research/reports/383/index.html

MUZET, V. and ABDO, J., 2018. On Site Photometric Characterisation of Cement Concrete Pavements with COLUROUTE Device. Light and Engineering. 26, pp. 88-94.

MUZET, V., COLOMB, M., TOINETTE, M., GANDON-LEGER, P., and CHRISTORY, J.-P., 2019a. Towards an optimization of urban lighting through a combined approach of lighting and road building activities. In: Proceedings of the 29th Quadrennial Session of the CIE, CIE. pp. 789-800. Available from: http://files.cie.co.at/x046_2019/x046-PP23.pdf

MUZET, V., 2019b. SURFACE database and test-set, impact on road lighting. Presented at Surface First webinar, June 2019. http://surface-nrm02.eu/

MUZET, V., GREFFIER, F., NICOLAÏ, A., TARON, A., and VERNY, P., 2019. Evaluation of the performance of an optimized road surface/lighting combination. Lighting Research \& Technology. 51 (4), pp. 576-591. https://doi.org/10.1177/1477153518808334 